BALANCE-OF -PAYMENTS THEORY AND THE UNITED KINGDOM EXPERIENCE 
Other books by the author

Growth and Development: with Special Reference to Developing Economies, Second Edition

Inflation, Saving and Growth in Developing Economies

Financing Economic Development

Regional Growth and Unemployment in the United Kingdom (with R. Dixon)

Keynes and International Monetary Relations (editor)

Keynes and Laissez-Faire (editor)

Keynes and the Bloomsbury Group (editor with D. Crabtree) 


\section{Balance-of-Payments Theory and the United Kingdom Experience}

\section{A. P. THIRLWALL}

Professor of Applied Economics

University of Kent at Canterbury

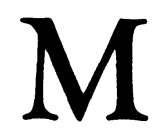


ㄷ A. P. Thirlwall 1980

All rights reserved. No part of this publication may be reproduced or transmitted, in any form or by any means, without permission.

First published 1980 by

THE MACMILLAN PRESS LTD

London and Basingstoke

Associated companies in Delhi Dublin

Hong Kong Johannesburg Lagos Melbourne

New York Singapore and Tokyo

Typeset by

Reproduction Drawings Ltd

Sutton, Surrey

British Library Cataloguing in Publication Data

Thirlwall, Anthony Philip

Balance-of-payments theory and the United

Kingdom experience.

1. Balance of payments - Great Britain -

History 2. Balance of payments - Case studies

I. Title

$382^{\prime} .17^{\prime} 0941$ HG3883.G7

ISBN 978-0-333-24368-8 ISBN 978-1-349-16246-8 (eBook)

DOI 10.1007/978-1-349-16246-8

This book is sold subject to the standard conditions of the Net Book Agreement.

The paperback edition of this book is sold subject to the condition that it shall not, by way of trade or otherwise, be lent, re-sold, hired out, or otherwise circulated without the publisher's prior consent in any form of binding or cover other than that in which it is published and without a similar condition including this condition being imposed on the subsequent purchaser. 
To Merlyn Rees, M.P.,

who first taught me to think and write 


\section{Contents}

Preface and Acknowledgements xi

1 Balance-of-Payments Accounting and the ForeignExchange Market

Concepts of the balance of payments 1

The accounting balance of payments 2

Balance-of-payments equilibrium 5

$\begin{array}{lr}\text { More on the concept of equilibrium } & 19\end{array}$

The foreign-exchange market 22

The demand for dollars $\quad 23$

The supply of dollars $\quad 26$

Capital movements and speculation $\quad 31$

The forward rate of exchange 33

$\begin{array}{ll}\text { Types of exchange-rate regime } & 37\end{array}$

Fixed versus flexible exchange rates 43

2 The Balance of Payments and the National Economy 48

The integration of the balance of payments into the national accounts 48

The conflict between balance-of-payments equilibrium and other objectives of economic policy 50

Income equilibrium in an open economy and the foreign-trade multiplier

The foreign-trade multiplier relating imports to expenditure

The 'new' foreign-trade multiplier with foreign repercussions 
Balance-of-payments adjustment $\quad 65$

The classical price-specie flow mechanism 66

$\begin{array}{ll}\text { The elasticity approach } & 67\end{array}$

The absorption approach $\quad 69$

The monetary approach $\quad 69$

3 The Elasticity Approach to the Balance of Payments 72

The Marshall-Lerner condition derived 72

Devaluation and the response of firms $\quad 78$

Lags and the $J$-curve effect $\quad 83$

Devaluation and inflation $\quad 85$

Devaluation and the terms of trade $\quad 92$

The difficulties of measuring price elasticities 93

4 The Absorption Approach to the Balance of Payments

The direct effect of devaluation on income $\quad 100$

The direct effect of devaluation on absorption 101

The interaction between changes in income and changes in absorption 103

Strengths and dangers of the absorption approach 105

The monetary aspects of balance-of-payments deficits $\quad 107$

Domestic credit expansion 108

5 The Monetary Approach to the Balance of Payments

6 Simultaneous Internal and External Balance

Internal and external balance under flexible exchange rates with no capital movements

Internal and external balance under fixed exchange rates with capital movements 
Internal and external balance in an $I S-L M$ curve framework

The use of monetary and fiscal policy under alternative exchange-rate regimes

The assignment of policies in the United Kingdom

\section{A History of the U.K. Balance of Payments}

1854 to 1939

1940 to 1950

1951 to 1959

1960 to 1969

Devaluation, 1967

1970 to 1980

Appendix 7.1: an economic analysis of the United

Kingdom's payments difficulties in the 1960s - the prelude to devaluation, 1967

Appendix 7.2: a polemic on floating the pound, 1972

\section{Import Functions}

The determinants of imports $\quad 194$

Imports and capacity 196

Imports and labour-market bottlenecks 200

Imports and income (estimates of income elasticities) 204

Imports and relative prices (estimates of price elasticities) $\quad 210$

Import penetration

\section{Export Functions}

The determinants of exports $\quad 222$

Exports and capacity 223

Exports and world income (estimates of income elasticities) 230

Exports and relative prices (estimates of price elasticities) 231

The United Kingdom's declining share of world exports 239

Appendix: commodity and geographic composition of U.K. exports and imports 
10 The Balance-of-Payments Equilibrium Growth Rate 251

The determination of the balance-of-payments equilibrium growth rate

A fundamental law of growth

11 Export-led Growth

The importance of export-led growth

An export-led growth model with a balance-of-payments constraint

12 The Balance of Payments as a Structural Problem

Non-price factors determining exports and imports

North Sea oil and the balance of payments

The balance of payments and de-industrialisation

References

Name Index 


\section{Preface}

This book has two main purposes: first, to provide an elementary exposition of the balance of payments and of balance-of-payments adjustment theory; and second, to challenge the relevance of conventional adjustment mechanisms as solutions to the United Kingdom's weak balance of payments.

Even before I started to do my own research and thinking about the balance of payments I was sceptical of the view that countries' balance-of-payments problems are primarily a function of adverse relative price movements which can be rectified by adjustments to the exchange rate. Where the scepticism originates I am not sure but it has spilt over into dissatisfaction with most of the textbooks on the balance of payments, and with their treatment of balance-of-payments adjustment theory, which more or less take for granted, with various degrees of qualification, that relative price adjustments through a change in the exchange rate will secure for a country simultaneous internal and external equilibrium. This was the driving intellectual force in fashion when the world moved to floating exchange rates in 1973.

My scepticism has been most acute in the case of the United Kingdom, which has experienced persistent difficulty in reconciling balance-of-payments equilibrium with full employment and a higher growth rate, and where, as it turns out, devaluation and currency depreciation have been singularly unsuccessful in reconciling the conflict.

My dissatisfaction is not confined to traditional neoclassical priceadjustment theory. It extends to the more recent monetary approach to the balance of payments which gives the impression, whether it intends to or not, that all balance-of-payments difficulties have their origin in monetary disequilibrium and that monetary correction is a sufficient condition for internal and external balance. 
It is argued strongly in the book, particularly in Chapters 10 and 11 , that the balance of payments must be viewed in a growth context, and that at the heart of the United Kingdom's economic difficulties is the slow rate of growth of exports, which cannot be raised permanently, if at all, by exchange-rate depreciation, and is not amenable to monetary manipulation. The problem requires real economic policies of a structural nature related to the wider characteristics of goods, such as their quality, design and reliability, marketing and delivery. Exchange-rate depreciation simply ossifies the industrial structure and makes manufacturers temporarily more competitive in the export of goods with given characteristics which were the source of the payments weakness in the first place. As I argue in Chapter 10, I am convinced in my own mind that the United Kingdom's inferior economic record in relation to other industrialised countries, particularly since 1950 , is largely a function of its balance-of-payments strait-jacket caused by the slow rate of growth of exports relative to other countries, and until this underlying weakness is rectified the United Kingdom will be condemned to a low growth rate and the spectre of rising unemployment whatever other domestic policies are pursued.

Apart from being an unusual (but I hope appealing and convincing) mixture of textbook and polemic, the book has two other features which distinguish it from traditional texts. First, it is argued strongly that the focus of balance-of-payments policy ought to be on the current account. To focus elsewhere, as the new monetary approach to the balance of payments urges, can store up trouble for countries in the future by delaying the real economic adjustments that a country must make ultimately. Second, for the first time in a textbook, the foreigntrade multiplier is presented relating imports to expenditure - this is obviously more realistic than relating imports to income if the import coefficients of various components of domestic expenditure differ.

Finally, an attempt has been made to organise the book in such a way that it can be used both as a preliminary text on balance-ofpayments theory and also as a source of reference on the performance of the U.K. balance of payments which can be updated in subsequent editions if the book proves useful to students.

In writing the book I am in debt to a number of organisations and individuals. The Social Science Research Council financed my research on labour-market bottlenecks and the balance of payments. During the project several other ideas were developed. The Treasury and the 
Department of Trade and Industry provided me with statistics. Mr John Goy and Mrs Julia Stevens of the University of Kent Library obtained and checked references for me. The editors of Banca Nazionale del Lavoro Quarterly Review, Applied Economics, the Oxford Bulletin of Economics and Statistics and the National Westminster Bank Quarterly Review gave me permission to reproduce certain material which first appeared in their journals. Mrs June Harrison typed the manuscript with superb efficiency. Finally, my colleagues Richard Disney, John Craven, Charles Kennedy, Bob Dixon and Thea Sinclair, helped to improve the book with their constructive comments on various chapters. To all these I am deeply grateful, but they bear no responsibility for the deficiencies which remain.

\section{A.P. T.}

\section{ACKNOWLEDGEMENTS}

The author and publishers wish to thank the following, who have kindly given permission for the use of copyright material:

Basil Blackwell Publisher Ltd, for a table from Oxford Bulletin of Economics and Statistics (November 1977); Cambridge University Press, for tables from Abstracts of British Historical Statistics, by Mitchell and Deane; The Controller of Her Majesty's Stationery Office, for tables from U.K. Balance of Payments, Key Statistics, and Economic Progress Reports; Lloyds Bank Ltd, for a table from Lloyds Bank Review (January 1975), by M. Panić; National and Commercial Banking Group Ltd, for a table from 'Floating Rates - Expectations and Experience', by Fred Hirsch and David Higham, reproduced in Three Banks Review (June 1974); National Westminster Bank Ltd, for a table based on figures from National Westminster Bank Quarterly Review (May 1975); Organization for Economic Co-operation and Development, for a table derived from OECD Manpower and Labour Force Statistics; Martin Robertson \& Company, for an extract from Modern Capitalism: Its Growth and Transformation, by J. Cornwall (1977). 